\title{
Parent-child Interactions during Co-reading Natural Science Storybooks
}

\author{
Hsu Chu-Chiao, Jui-Ching Cheng, Chou Mei-Ju*
}

Department of Early Childhood Education, National Pingtung University, Taiwan

Copyright $\bigcirc 2016$ by authors, all rights reserved. Authors agree that this article remains permanently open access under the terms of the Creative Commons Attribution License 4.0 International License

\begin{abstract}
In an age with rapid development of science and technology, how to cultivate the young generation's scientific literacy becomes extremely important. The study aims to investigate the dynamic process of parent-child co-reading natural science storybooks. Through children's exploring and experimenting daily life science with parents' scaffolding in five reading strategies, including Predictive Strategies, Connective Strategies, Summary Strategies, Summary for Them Strategies, and Note Taking Strategies, the integrated information and analysis results were as follows: First, children with different learning styles had different strategies to read science books. Next, parents need to select appropriately tailor-made reading strategies to enhance children's reading motivation. Thirdly, parent-child co-reading strategies do help improving the children's scientific literacy; children hence had higher interest in absorbing and applying to natural science knowledge, ability as well as more positive attitude towards exploring science.
\end{abstract}

Keywords Natural Science, Storybooks, Parent-child, Co-reading, Scientific Literacy

\section{Introduction}

Programme for International Student Assessment (PISA) is a multi-national student quality survey held by From the outcomes from Taiwanese students' participation in Programme for International Student Assessment (PISA) (PISA in Taiwan, 2012; Learning Strategy Net, 2014)[1][2], it can found that the main problems in science education in junior high school in Taiwan include over-emphasis on knowledge and entrance exam of higher education, lack of ability to form scientific ideas and propose scientific proofs, and lack of self-confidence in scientific programs. Under the prospective trend of digital exploration learning, teachers' exploration teaching literacy is indispensible (C. W. Wang, 2010; F. H. Tien, 2014).[3][4] In Taiwan, due to emphasizing children's performance of exams, scholars consider that developing children's scientific quality from childhood can facilitate their learning effect.

Ho Shiang-ju, et al, (2012) [5]held that science is originated from curiosity, and scientific observation and experiments support objective explanations and the existing facts. Additionally, logic deduction and effective induction with validity rely on generalizations and arguments in the restricted data for people to respond to how people perceive the world. Yung (2008) [6]postulated that since children are continuation of life and future of the world, what childhood education personnel have to do is to try to observe their learning style and the difficulty in learning, and provide "several" or "a large quantity" of learning approaches for guiding them to open the door to learning. In this regard, "parent-child co-reading" can be taken as the best way to inaugurate reading motivation.

As Akerson, V. L., et al, (2010) [7] and Shaywitz, S. (2008)[8] indicated, children are a born scientist who is extremely curious of the world. They love to operate stuffs with hands and observe variation of things, so natural science programs can match children's learning properties. The central goal of science education programs is to drive children's motivation to observe natural phenomena. National Year of Reading Popular Science (2010)[9] found in their research that students highly like story-based programs, especially the story-typed relative to scientists. As to exploration of parent-child co-reading science, it can form students' scientific concept, as researchers (Ansberry, \& Morgan, 2010; Bracken, \& Fischel, 2008; Cheng, Yeh-Chu; 2011; Hus, 2008; Hus, 2013; Mantzicopoulos, \& Patrick, 2011; Wu, 2006) [10][11][12][13][14][15][16]proposed that parent-child co-reading can establish students' concept of correct learning and reading, and it is a good way to shorten parent-child distance. Consequently, the researcher intended to melt scientific exploration activities into daily life. With family as the starting point, natural science picture books can be exerted to develop children's interest in science-related issues gradually. Also, in daily life, we can lead the children to cultivate scientific literacy by taking part in scientific exploration activities so that the journey of dynamic parent-child co-reading can embark and go on continuously. 


\section{Research Purposes}

Based on the research motivations mentioned above, the purposes of this paper are listed below:

(1) Explore similarities and differences of different children's learning style in their guided reading of natural science picture books.

(2) Explore similarities and differences of children with different learning styles to have parent-child co-reading of natural science picture books.

(3) Explore the methods to raise children's motivation of reading natural science picture books.

(4) Discussion on the strategies helpful for cultivating children's scientific literacy with reading natural science picture books.

\section{Definition of Nouns}

\section{Natural Science Picture Books}

The primary purpose of the natural science picture books in this research is to deliver scientific concepts and knowledge, cultivate children's scientific attitudes, and apply to natural science and scientific facts or concepts.

\section{Dynamic Parent-child Co-reading}

In "Manual of National Children's Reading in the Week of Reading", parent-child co-reading refers to all family reading together, or family reading group (Chiong, C, 2012; Lauricella, A. R.)[17][18]. In this study, dynamic parent-child co-reading means parents' reciting stories for the child, and guide or lead the child to ask questions, converse, discuss. and share with the child at proper moment based on the content of the picture book in order to explore natural science.

\section{Reading Strategies for the Natural Science Picture Books}

Reading strategies for the natural science picture books in this research signifies exertion of natural science books with the three elements in KWL teaching strategy K, W, L (what do I know, what do I want to know, what did I learn) proposed by Ogle (1986) as the central axis to emphasize connection of students' new and old experiences. Ogle (1986)[19] and Herrell, \& Jordan, (2015)[20] stressed that students are active learners who will explore and resolve problems actively in order to absorb new knowledge.

\section{Scientific Literacy}

Scientific literacy have been proposed by many researchers (Bybee, R., et al, 2009; Bybee, R., 2015). [21][22]In Programme for International Student Assessment and Grade 1-9 Curriculum Guidelines, scientific literacy refers to:

(1). Have basic natural science knowledge and the mental operation ability required in process of exploring science; (2). Have the ability to deduct and criticize things with natural science knowledge, and the ability to solve problems and integrate information, and understand scientific discovery and technology development process; (3). Have the attitudes of seeking for truth, exploring issues, and perceiving science, have the ability to solve problems by applying natural science knowledge and exploring methods. In this research, scientific literacy is defined as (1). Interest in absorbing and applying natural science knowledge; and (2). Attitude of exploring science; (3). Ability and skill of taking part in the process.

\section{Related Literature}

In this chapter, Section 1 discusses natural science picture books, Section 2 is definition of parent-child co-reading and theoretic foundation of co-reading, Section 3 explores reading strategies for the natural science picture books, Section 4 probes into scientific literacy, and Section 5 discusses studies related to this research to serve as the theory and the foundation of research design of this research.

\subsection{Natural Science Picture Books}

\subsubsection{Definition of Natural Science Picture Books}

Ganea, P. A., et al, (2008) [23]postulated three type picture books-- story-based science picture books, information-based science picture books, and imagination-based science picture books. The three types of science picture books aim to deliver scientific messages. Yang, Y. Y. (2008) [24] considered that natural science picture books involve subject of natural science knowledge, and the content covers natural science. Besides, the authors present scientific facts and concepts by fiction and non-fiction with relatively large portion of pictures in the book to help explain scientific messages. Yang (2010) [25]\& Yang (2013) [26]considered that if books aim to deliver natural science or scientific facts and concepts with pictures and texts, such works are called natural science picture books. "The Magic School Bus--Natural Science Picture Book Series used by this research belong to "story-based science picture books". We selected "Big Discovery of Circuit" and "Travel of Little Raindrop" as the axis to deliver natural science knowledge on "electricity" and "water".

\subsubsection{Functions of Natural Science Knowledge}

Picture books are children's "Food of Soul", and the treasure of children in $21^{\text {st }}$ century. Research (Akerson, \& Hanuscin, 2010; Armbruster, 2010; Fleer, 2015; Holbrook, \& Rannikmae, 2007; Lai, 2012; van den et al, 2009)[7][27][28][29][30][31] further claimed that children aged 4-6 are in the initial stage of developing self-concept, and picture books related to living and psychological growth can be offered for the children to understand themselves, and further facilitate the positive development of children, others, and environment. Students aged 6-8 have rich imagination, and they love mythology, fairy tales, and interesting literary picture books. Children aged 8-10 like to figure out various phenomena in the real world, so their reading interest 
involves nature, science, exploration, and autobiography related picture books. Ganea, P. A., et al, (2011)[32] indicated that reading story-based scientific picture books can help children understand and memorize scientific concepts, and it is even more effective than concepts listed in textbooks.

Sackes, M., et al, (2009)[33] generalized the advantages of natural science picture books by integrating viewpoints of many scholars:

Natural science picture books can

(1). Provide teachers exploration methods;

(2). Improve students' problem solving skills;

(3). Teach children scientific rules and surprise at finding;

(4). Enhance students' creative ability and thinking skills.

\subsubsection{Relative Teaching Studies on Natural Science Picture Books}

\section{(1) Assist Teaching with Natural Science Picture Books}

By stimulating children's cognitive learning, Elia, I., et al, (2010) [34] and van den Heuvel-Panhuizen, M., et al, (2009) postulated three type Science Picture Books: "Imagination-based", "story-based", and "information-based". In research of scientific story programs' influence on Grade-5 students' perspective on nature of science and their attitudes towards science, research (Lin, 2008; Lin, 2010; Schweingruber, et al, 2007; Williams, J.A., et al, 2012; Carson, 2011) [35][36][37][38][39]utilized the designed scientific story program to teach the students and observe the influence on Grade-5 students' "nature of science" and "attitudes towards science". Smolkin, L. B., et al, (2009) [40]claimed that melting scientific stories into natural science programs show that students like story related classes remarkably, especially those involving the scientists, leading to their positive attitudes towards science.

\subsection{Cultivate Scientific Literacy with Natural Science Picture Books}

$\mathrm{Yu}$ (2012)[41] attempted to comprehend how reading science picture books changes students' attitudes towards science and motivates their interest in science. The research found that Grade-4 students' attitudes towards science are improved as a whole after reading scientific picture books. Children like to read science picture books, and tend to be attracted by images. From reading science picture books, students can perceive "scientific recognition", "scientific affection", and "scientific behaviors".

Sagan (2011) [42]revealed that science served as a candle in the dark; furthermore, research (Landt, 2015) [43]postulated that teaching strategies of guiding students to learn science through picture books lead to (1) with the situation in "story-based science picture books", students can probe meaningful natural science knowledge learning; (2) before "individual reading", the class can "share together", triggering students' motivation to further read picture books.
Ansberry, \& Morgan, (2007) [44]indicated in her study on scientific concept learning of students with different cognition styles, and the results are (1) the elements in science picture books that influence students' concept learning includes interaction between image and text; (2) regardless of image extraction and interpretation of data or construction of concepts, the students are influenced by the personal style (image style and text style). Smolkin, L. B., et al, (2009) [40]explored the question types proposed of elementary school students, and the research revealed as follows. (1) what students proposed are mostly cause-based questions involving "why" rather solution-based questions involving "how"; (2) it is found that the source of students' questions is mostly originated from curiosity for the story situation; (3) only a few students can truly retrospect and analyze their proposed questions; (4) most questions proposed by the students match the scientific issues in the books. From the above studies, the researcher generalized that natural science picture books can indeed motivate children to read and influence on their "attitudes towards science". They therefore hold positive attitudes towards science, and are highly interested in story classes and love science. Because of their love for reading science picture books, they perceive "scientific recognition", "scientific affection", and "scientific love". With children's learning science begins with experiences in their own world, Fleer (2015) [28]considered that there are three criteria in judging a good science books: 1. Correct: Students have limited living experiences, and the terms they use are not as difficult as teachers; so simple wording that can deliver scientific concepts correctly is more appropriate. 2. Popular: Popular science books do not stick to any conventions; rather, they are new, keep up with the current trend, change continuously, and are always pursuing the truth and the most appropriate experimental methods by consistent modification. 3 . Appropriate: Selection of the subject must start from students' basic objects in their living environment to arouse their interest in exploring.

\subsection{Relative Theoretical Foundation of Parent-Child co-reading}

From sharing and dialogues in process of parent-child co-reading, the method of sympathy and interaction is established and the individual difference from children is observed. The researcher consulted relative theoretical foundation for application to the whole process of parent-child co-reading. Bracken, \& Fischel, (2008)[11] thought that in addition to parents' critical role in planning co-reading in the beginning, the way parents interact with children is also the key element of success of co-reading. As far as family is concerned, parents and child's sharing a children's book is called "parent-child co-reading". In process of parent-child co-reading, parents have to understand child's recognition ability and explore his or her reading interest in order to select appropriate reading materials for him/her. In this study, the researcher consulted 
the relative theoretical foundation of parent-child co-reading to develop "dynamic parent-child co-reading".

Concerning parent-child co-reading model, S. E. Mol, et al, (2008)[45] proposed elementary school children's co-reading skills in "Reading begins with family co-reading" as follows: (1). Recite the book with child by turn, and encourage the child to recite the book with different tones to express different emotions. (2). Develop child's ability of in-depth reading. (3). Guide the child to compare his/her reading materials. Parents have to encourage the child to compare what he/she is reading to other books that he/she is familiar--what are the similarities and differences in the roles in the books, and whether the two books have the same background? (4). Develop Child's Critical Ability for What $\mathrm{He} / \mathrm{She}$ Is Reading. Parents can talk with child about the most impressive part in the book. (5) Have the Child Understand the Arrangement of Writing. (6). Encourage Child to Have Systematic Reading: If the child have already read certain number of books, parents can encourage him/her to collect an author's works or books with certain subject for systematic reading. On the same pace, Ganea, P. A., et al, (2008) explored the guiding behaviors of the mother in parent-child co-reading, and they coded mother's lingual behaviors with 8 categories: (1) Pay attention to oriented behaviors and simple object messages; (2) Experience connection; (3) Dramatic expressions; (4) Description of story texts; (5) Description of plot; (6) Comment on the story; (7) Feedback; (8) Ending question. Bracken, \& Fischel, (2008) [11]generalized common strategies for parent-child co-reading, and found the following items: (1) Recite and repeated reciting; (2) explanation and description; (3) generalization and estimation; (4) experience connection; (5) knowledge extension; (6) recalling text; (7) reciting by pointing at the text.

To sum up, regarding selection and exertion of strategies for parent-child co-reading, parents also have to extract the context from daily parent-child co-reading interaction in order to connect old experiences with new knowledge and further extend child's learning.

\subsection{Relative Theoretical Foundation of Parent-Child Co-Reading}

Generally, parents' intention of parent-child co-reading is to construct child's abilities of cognition, moral, character, language, and etc. by means of parent-child co-reading. One of the goals in this research is to construct children's scientific literacy by means of natural science picture books. The researcher claimed that by integrating and generalizing Relative Theoretical Foundation of Parent-Child co-reading, it is further found providing reading strategies for natural science picture books with better learning effect can bring parent-child co-reading function into a full play. Vygotsky (1978)[47] signified that children's learning development can be categorized into the existing standard and the potential developing standard; and, by interactive cooperation with the adults and peers, they can transcend the existing standard. The US cognitive psychologist Ausubel (2012) [48]claimed in his Meaningful Learning Theory that during the individual's learning new concepts, he/she uses the existing prior knowledge and tries integrate it into the old cognitive structure, and further assimilate it as his/her own knowledge.

\subsubsection{Vygotsky's Social Learning Theory}

Vygotsky's social learning theory employs scaffolding and social interaction to stress on the function of dialogue and cooperative learning. Scaffolding refers to children's growth of internal psychological ability relies on help from the adults, and such help should be established on the learner's then-current cognitive foundation. When the adults provide guidance systematically, the learner tends to surpass the original level more easily.

Therefore, in process of parent-child co-reading in this research, the utilization of scaffolding theory must be subject to the following principles: (1) Understand the child's old experiences, the ability they already have, and their starting point of learning; (2) Control child's existing abilities and difference between parents' expectation of child and the child's actual abilities; (3) Set up definite goals for guiding reading, and assist development in reading guiding activities-- assembling scaffolding; (4) From "assisting performance" into "independent performance"-- dissembling scaffolding. With parents' understanding the child's actual ability and knowledge via methods or strategies like modeling, immediate treatment, feedback, instruction, questioning, and cognitive structure, co-reading activities should be located at "near side developing area." Finally, with parents' guidance and child's internalization, the child's reading ability can be raised.

\subsubsection{Meaningful Learning Theory}

The US cognitive psychologist Ausubel (2012) [48]indicated that, meaningful learning only exists in teaching students new knowledge based on the foundation of their prior knowledge. Meaningful learning emphasizes that, if new messages relate to the existing "cognitive structure" in the individual's nervous system in the brain, the new messages can take root in the existing conceptual system. From Meaningful Learning Theory, the researcher deducted three directions for co-reading strategy: (1) how to organize natural science picture books in order to have children generate meaningful learning; (2) how to absorb new knowledge through old experiences when children face new knowledge they are going to learn; (3) in guiding children to learn the knowledge in picture books' content, how the researcher exert Meaningful Learning Theory to achieve the goal of co-reading.

\subsection{Discussion of Reading Strategies Form Natural Science Picture Books}

"Guidance to reading" is a kind of parent-child co-reading, meaning parents' guiding the child to read the text. With 
guidance to reading, children have more diversified and rational viewpoints. Based on the learner's learning style, the researcher employed KWL reading strategy for natural science picture books as the central axis to proceed systematic and orderly guidance to reading activity in process of exerting natural science for parent-child co-reading. Learning style theory has two major characteristics; one is the process of care for learning, including how the individual absorb, think, and evaluate the results. The other is connection with personality characteristics, considering that learning is the process of individualized thinking and experience. Kolb, et al (2001) proposed that learning style scale according to two constructs-- information perception, and information processing. Based on whether the individual exerts the physical experiences or the abstract concept, and active experiment or retrospective observation, he classified the general's learning styles into four types, which is described as follows: (1) Convergent: The learners are inclined to abstract concepts and active experiments, and good at obtaining knowledge through experiments done in person, solving problems, making decisions, and putting thoughts into practice. (2) Divergent: The learners are inclined to physical experiences and retrospective observation. They are imaginative, and sensitive to meaning and value. (3) Assimilation: The learners are inclined to abstract concepts and retrospective observation. They are skilled at generalization and logic thinking, creation of theory model to integrate and explain observations from various sources.

(4) Accommodative: The learners are inclined to physical experiences and active experiments, and good at doing things personally, carrying out plans, and participating new tasks.

\subsection{Process of Reading Comprehension}

Most research on reading comprehension focus on influence of reading teaching intervention strategy on reading comprehension ability, including literal comprehension, inferential comprehension, and comprehension monitoring. Duke, \& Pearson (2008) [50] proposed that there are four models reading comprehension, including (1) Bottom-up Model: It emphasizes on process of decoding, and it mainly holds that reading is a bottom-up process from visual treatment, text recognition to memory and comprehension. Bottom-up model is also called text-based model. (2) Top-down Model: It highlights readers' prior knowledge and living experiences. It also stresses on the wholeness is larger than sun of parts, so it is oriented to wholeness method, and proper for those who have better reading ability, rich common knowledge and experiences. (3) Interactive Model: It is the representative of this school, and he considers that reading will be influenced by prior knowledge, reading strategies for natural science picture books, and article decoding process. As a result, it is suggested that students exert their background knowledge and decoding skills to find the meaning in the article. (4)
Recycling Model: It emphasizes that reading process recycles continuously rather than proceeding linearly. In addition to agreeing that reading is influenced by prior knowledge and reading strategies, it holds that reading is also affected by social situations, and it stresses on situation in interactive process will impact reading strategies.

Ministry of Education in Taiwan entrusted Graduate Institute of Learning and Instruction of National Central University to conduct "Plan of Reading Teaching Strategy Development and Promotion" to compile the Manual of Reading Comprehension Strategy Teaching. In the manual, it refers to five common reading strategies in the relative research reports, including Predictive Strategies, Connective Strategies, Summary Strategies, Summary for Them Strategies, and Note Taking Strategies. The researchers consulted the above-mentioned reading strategies to develop the reading strategies for natural science picture books in this research.

Concerning reading strategies for natural science storybooks, The researcher consulted teaching practice for natural science territory in Grade 1-9 Curriculum Guidelines and designed her own strategies for guiding reading process: (1) Guide reading requires theme, planning, and progressive steps; (2) Guide reading activities must include extended exploration activities; (3) Exert learning resources like visiting the Science and Technology Museum; (4) Make good use of media resources such as parents and children's watching scientific programs together; (5) modeling before instructing experiment's operative procedures; (6) He who guides reading cannot limited to reciting word by word; (7) adjust guide reading methods based on children's learning styles.Next, the researcher consulted teaching practice for natural science territory in the above-mentioned Grade 1-9 Curriculum Guidelines and designed her own strategies for guiding reading process: (1) Refer to child's old experiences to arrange scientific exploration suitable for children with different ages and abilities; (2) In proposing questions for guide reading, it requires skills and chances to interact and discuss with children; (3) Seek for assistance of the experts, like participants with electric engineering background; (4) deliver scientific principles by language understandable to the children; (5) In addition to parent-child co-reading, develop sibling co-reading; (6) guide reading is not only delivery of natural science knowledge but also application to natural science knowledge in order to solve problems; (7) there is no stress on guide reading process; rather, children's interest is the priority, so do not hurry; (8) ability to take part in the process and operate manually in person.

\subsection{K-W- L Reading Strategies for Natural Science Picture Books}

This research adopted natural science picture books as media, and drove children's interest through dynamic parent-child co-reading and familiar science issues in living environment, so that children's old experiences can connect with new knowledge. What follows discusses KWL reading 
strategy for natural science picture books employed by this research.

KWL teaching strategy was proposed by Ogle (1986) [19] to highlight connection of students' old and new experiences on basis of concept of constructivism. It considers students as an active learner who positively explores and solves problems in order to absorb new knowledge. KWL teaching strategy is composed by three elements--K, W, L, and the teaching procedures are listed below: K (What do I know): For the theme or issue we are going to learn, what do I know? $\mathrm{K}$ is the prefix of the English word know, meaning students' prior knowledge and old experiences. W (What do I want to know), and for the theme L (we are going to learn?) In process of teaching and learning, if it is teacher that works as the decision maker for learning focus, students are often passive one-way learners that absorb knowledge.
After stage $\mathrm{K}$ and $\mathrm{W}$, and before stage L, children could take part in the main learning activities, and attempt to solve the problem proposed by themselves by observation, experiment, discussion, and etc.

Students can refer to the record in $\mathrm{K}$ and $\mathrm{W}$ to examine the correctness of the old experiences and whether they have solved the problem in process of learning. In such activities, students learn to evaluate themselves, connect new and old experiences, and answer the questions in the previous stages consciously.

\subsubsection{Further Discussion and Exploration}

Empirical Research on KWL Strategy in Taiwan

What follows generalize and compare the studies relates to scientific literacy most significantly in this research, as Table 1 shows:

Table 1. Empirical Studies Related to KWL Strategy In Taiwan

\begin{tabular}{|c|c|c|c|c|}
\hline Theme & Researcher & Object & Method & Results \\
\hline $\begin{array}{l}\text { Case study on students' } \\
\text { learning sun related concept }\end{array}$ & Hershberger(2006)[51] & 36 Grade- 5 students. & $\begin{array}{c}\text { Observation, } \\
\text { semi-structural } \\
\text { interviews, concept } \\
\text { diagrams, and KWL } \\
\text { graph }\end{array}$ & $\begin{array}{l}\text { Understand students' } \\
\text { concept regarding sun } \\
\text { before and after learning, } \\
\text { and explore factors that } \\
\text { affect students from social } \\
\text { and cultural perspectives. }\end{array}$ \\
\hline $\begin{array}{l}\text { Mobile research that } \\
\text { enlighten students' creativity }\end{array}$ & Martinez el al(2004)[52]. & elementary students & $\begin{array}{l}\text { Main activities with KWL } \\
\text { strategy penetrating } \\
\text { through the whole process }\end{array}$ & $\begin{array}{l}\text { Students' positive growth } \\
\text { involving tolerance, } \\
\text { self-discipline, and } \\
\text { creativity } \\
\end{array}$ \\
\hline $\begin{array}{l}\text { Utilize KWL media teaching } \\
\text { strategy to probe into } \\
\text { Grade- } 5 \text { students' learning } \\
\text { effect in Earthquake Unit }\end{array}$ & $\begin{array}{l}\mathrm{Fu}[53] \\
(2006)\end{array}$ & $\begin{array}{l}\text { Students from two } \\
\text { Grade- } 5 \text { classes }\end{array}$ & KWL as teaching strategy & $\begin{array}{l}\text { The existing KWL } \\
\text { teaching strategies can } \\
\text { enhance Grade- } 5 \text { students } \\
\text { learning effect of } \\
\text { earthquake unit, and their } \\
\text { creative performance in } \\
\text { making a little book }\end{array}$ \\
\hline $\begin{array}{l}\text { Connect language with } \\
\text { science learning--KWL } \\
\text { teaching strategy applied to } \\
\text { stage of children }\end{array}$ & $\begin{array}{l}\text { Miller[54] } \\
\text { (2009) }\end{array}$ & $\begin{array}{l}\text { A Grade- } 2 \text { class and two } \\
\text { kindergartener classes }\end{array}$ & $\begin{array}{l}\text { Observation, interviews, } \\
\text { and collection of relative } \\
\text { documents }\end{array}$ & $\begin{array}{l}\text { (1)Students take part in } \\
\text { discussion activities even } \\
\text { more actively and more } \\
\text { confidently; (2) Teachers } \\
\text { can utilize discussion in } \\
\text { stage K and Was tools to } \\
\text { activate and evaluate } \\
\text { students' related } \\
\text { background knowledge. } \\
\text { Discussion in stage K can } \\
\text { help students retrospect } \\
\text { their own learning } \\
\text { outcomes. }\end{array}$ \\
\hline $\begin{array}{l}\text { Research on impact of } \\
\text { reading comprehension } \\
\text { teaching of children's } \\
\text { popular science readings on } \\
\text { learning natural science in } \\
\text { elementary school. }\end{array}$ & $\begin{array}{l}\text { Zembal - Saul, C. } \\
\text { (2009)[55] }\end{array}$ & $\begin{array}{l}\text { Students in three Grade-3 } \\
\text { classes }\end{array}$ & $\begin{array}{l}\text { Reciprocal teaching } \\
\text { method aided by KWL } \\
\text { teaching sheet }\end{array}$ & $\begin{array}{l}\text { Students hold positive and } \\
\text { active attitudes towards } \\
\text { popular science readings, } \\
\text { and consider learning } \\
\text { sheet can help memorize } \\
\text { concepts. }\end{array}$ \\
\hline
\end{tabular}


From the above listed research related to science, regarding this research subject, KWL natural science picture book reading strategy is feasible to be applied to science issues. In addition, on the age of the research subject, it ranges from kindergarteners to Grade- 6 students, proving the correctness of the researcher's application of KWL. From the method to collect data, KWL reading strategy for natural science picture books can be regarded as either the reading instructive strategy that penetrates the whole research or just the assistant strategy. In this paper, the researcher applied natural science picture books to proceed the process of parent-child co-reading to explore whether natural science picture books to develop and construct children's scientific literacy. During implementation, KWL model was employed; that is, what do I Know, what do I Want to know, and what did I Learned were used as the standard of question proposals.

\subsection{Discussion on Implication of Scientific Literacy}

For "literacy", when nurtured internally, it refers to knowledge, viewpoints, and concept; while presented externally, it means ability, skills, and attitudes.

PISA (the Programme for International Student Assessment) includes formal and informal environments, such as formal programs, extracurricular clubs, family environment, school atmosphere, and the like. The following framework of PISA related scientific literacy has set up indicators based on PISA 2006: (1) When we encounter science related issues, natural science knowledge can be used to discover problems, form new knowledge, explain phenomena, and obtain conclusion based on facts; (2) Whether we can use natural science knowledge to support our decisions, and realize that science is knowledge formed by people's exploration; (3) We can be aware that science and technology influence on the material, intellectual, and cultural surroundings deeply; (4) whether we can understand how change of environment affects social stability and economic development, and are willing to take part in science related social issues or ideas of science with identity of citizenship. From three PISA test frameworks, three ability dimensions of scientific literacy are generalized: (1). Scientific Ability Literacy: PISA 2006 Science Test concentrates on students' three performances in scientific ability literacy-- ability of scientific issue literacy, ability of scientific phenomena explanation literacy, and ability of scientific ability literacy. (2) Natural Science Knowledge Literacy: knowledge of scientific knowledge, and nature of science, stressing on how scientists use data to explain phenomena of Mother Nature. (3) Scientific Attitude Literacy: PISA scientific attitude literacy was drawn up by OECD's survey results in 2006, including the following items: support for scientific exploration; confidence in scientific learning; interested in scientific learning; and conscious of personal responsibility of environment and resources.

\subsubsection{Natural Science Literacy in Grade 1-9 Curriculum Guidelines, Ministry of Education}

In Grade 1-9 Curriculum Guidelines of Ministry of Education, "raising national's scientific literacy" is regulated as the primary goal in scientific education in Nature and Living Technology Territory. In fact, the new curriculum emphasized that value of knowledge does not lie in memorizing knowledge, but in enlightening students' diversified wisdom to cultivate life-time abilities through knowledge.

Ministry of Education replaces Curriculum Standard with curriculum guidelines, schools should set up their own curriculum with the flexible space provided for each school to develop characteristic curriculum. In curriculum guidelines for nature and living science programs, "scientific literacy" is divided into eight parts as below: process skills, cognition of science and technology, nature of science, development of technology, scientific Attitudes, thinking ability and skills, application of Science and design and making.

To sum up, this research consults PISA 2006 and scientific literacy in Grade 1-9 Curriculum Guidelines, and generalizes that scientific literacy refers to: (1) basic natural science knowledge and mental operation ability in scientific exploration process; (2) To explore things with scientific deduction, and have integrative scientific thoughts and information integration ability, and realize scientific finding and technology development process; (3). Attitudes that seek for the truth of things, love to explore things, and perceive scientific attitudes, and apply natural science knowledge and explorative methods to solve problems. In this research, the researcher intends to probe into whether the child possesses the following scientific literacy in the process of using natural science picture books to carry out parent-child co-reading: (1) interest in absorbing and employing natural science knowledge; (2) scientific exploration attitudes; (3) ability and skills in participating process.

\section{Research Design and Implementation}

\subsection{Pilot Study}

Practice of pilot study aims to help the researcher understand children's reaction to natural science picture books. One year before my formally conducting this research, I purchased "Magic School Bus--Natural Science Picture Book Series", and implemented informal parent-child co-reading from winter vacation in January, 2013, to January 2014, in order to be more assured of the research purposes when formal research was once conducted. There are three items in pilot study: (1) Before co-reading of scientific picture books, the researcher has to be very clear about the content of the picture books; (2) The methods for the researcher to use scientific picture books must be diversified; (3) The researcher has to control different children's various 
reactions to picture books. To help children learn scientific concepts and internalized scientific thinking model, the research decided to use "dynamic parent-child co-reading" to guide children to read natural science picture books.

\subsection{Research Process}

According to the purpose of this research, the researcher exerted natural science picture books to practice process of parent-child co-reading. With case study as the axis, KWL modeled reading strategy for natural science picture books were integrated to explore and implement research themes. The flow chart of the research can be seen in the following statement. 1. pilot study; 2. Collect and modify relative literature; 3. Develop pre-test interview sheet; 4 . Proceed the first guide reading; 5 . Proceed post-guide-reading interview and discussion; 6. Proceed the second guide reading; 7. Operate manually; 8. Publish time; 9. Proceed post-guide-reading observation; 10 . Research analysis

\subsection{Research Participants}

The researcher was the home-room teacher of the research subject-- the preschool children; therefore, she had good understanding of the students in her class, which made it easier for her to design and arrange learning activities that can arouse their learning interest and motivation. After delivering parents agreement for attending the research, three study subjects were recruited. In this section, the researcher describes case-1 Shao-yo's and case-2 Shao-shi's age, personality traits, learning condition and scientific literacy-related learning condition. Besides, the education degree, experiences, and teaching philosophy on scientific literacy of the research participants and the researcher are described as well.

\section{Study subject-- Shao-yo in Grade-1}

Shao-yo is 6 years old in the transition between kindergartener to Grade-1 stage when she participated the research. She is easy-going, the youngest child in her family, Gemini. Her language style is humorous, tends to add personal observation and subjective opinions when she narrates facts, and she can use self-created words or body language or pictures to express and deliver messages.

Shao-yo is optimistic and popular among classmates in teacher's eyes. If there is student who is hard to get controlled, the teacher will always ask him/her to sit beside Shao-yo. Shao-yo is independent and autonomous in learning, and is rich of her own viewpoints.

\section{Research Subject Shao-shi in Grade-3}

Shao-shi is 8 years old with fair language expression ability, and can completely narrates what she sees and hears. Since childhood, her learning experiences like entrance exam to piano major in musical class and cultivation of reading habits are all taught by her parents at home, and her interest in reading and ability has been appreciated by teachers in each grade.

Regarding Shao-shi's scientific literacy related learning condition: When she was in Grade-1, the researcher found she has "reading in eclipse"; therefore, the researcher started from visiting Science and Technology Museum to cultivate her interest and through natural science educative program in school.

\section{Research Participant-- Father of the Case Study}

In Shao-yo's eyes', Father is a good-tempered and generous man with college and two-year technology school degree, majoring in electronic engineering, and is now working in an electric power company. Case is not strange to electric tower, electric cables, electromagnetic wave, high-voltage electricity, and etc. For case's questions about electricity, he can answer with positive attitude, certainly a father who passively joins education with strong-motivation.

\section{Researcher--Mother of Case Study}

The researcher was graduated from science and technology department and research institute, to education territory. Besides, she took "Special Children's Teaching Education Program", "Research on Children's Museum", "Research on Scientific Science", "Research on Curriculum Design in Kindergarten", and the related educative programs related to this study. Her working experiences relative to this research are substitute teacher". Therefore, it should be easier for the researcher to find and employ teaching strategies for children with different learning difficulty than other mothers. On natural science knowledge, there are more old experiences to get connected.

\subsection{Research Tools}

\section{Selection of Research Tools--Natural Science Picture Books}

"Magic School Bus Series" selected by the research are published by the prestigious U.S. publish company Scholastic. With the top scholars and experts in US natural science circle, outstanding children's literature authors, and the famous artists, "Magic School Bus Series" has become the most influential, popular, and hot children's natural science picture book series with the most awards. Also, popular science readings are very popular in US, since the earliest "Little Raindrop's Travel" in 1986, books in the whole series Magic School Bus" were published one after another. As New York Times commented, "for children, this is the freshest, the most interesting, imaginative, and creative way for scientific enlightenment". "Magic School Bus Series" was awarded as the most popular children's science cartoon in US TV programs. More than 10 millions of children's scientific picture books were sold in US, and were quite popular. The whole series was awarded with 5 -star evaluation in US New York Times book comment and "Amazon International Internet Bookstore", so the research was motivated to choose it as the research tool. 


\section{Content of Research Tool}

The First Co-reading of Natural Science Picture Book-- "Big Adventure of Circuit"

\section{A. introduction of "Big Adventure of Circuit"}

Story begins with an experiment of electricity in Teacher Fo's class. All of a sudden, power cut, so the whole class decided to go out by bus to see what had happened. They went to the street to see how personnel in electric power company repair an electric wire stricken by flash flail? Then, the teacher led the whole class and the bus shrunk as smaller than the wire. By this way, students and the teacher entered into the wire and followed along the route of the electric wire to go through "Adventure of Electricity". They arrived at the power plant first, and to the toaster to see how it baked toast. Then, they went into the electric device in Phoebe's home to see how the electric saw sawed stuffs, and how the vacuum cleaner eats dusts. Finally, all students got out from the school's socket and returned to classroom. In this trip filled with "electricity" and "imagination", most of the children's questions were answered, so they were satisfied and motivated to explore what they were curious with the researcher.

\section{B. Why the Researcher Used "Big Adventure of Circuit" as} the First Research Tool

By this book, the researcher began with the most tiny and fundamental places, and dig into nature of things. Students observed and thought scientifically while doing experiment. In our daily life, we encounter questions regarding electricity every day, like "what is electricity" and "where does electricity come from".

The Second Co-reading of Natural Science Picture Book--"Travel of Little Raindrop"

\section{A. Introduction to "Travel of Little Raindrop"}

Curl-haired Teacher Fo led a class of naughty children to fly to the cloud by magic school bus to experience travel of little raindrop. From clouds' turning into little raindrops, falling to the small stream in the mountain, wandering and finally converging to the reservoir, and sent to the water purification plant to take a bath, and getting sterilized. Then, they were stored in the standpipe, and distributed to everyone's home through water pipes.

B. Why the Researcher Used "Travel of Little Raindrop" as the Second Research Tool

The author presents a common subject and serious water treatment process interestingly and skillfully with funny dialogues, editing skills for story inference to have the children understand knowledge of water and concept of environment preservation.

For the pre-test semi-structural questionnaire, this informal questionnaire is homemade by the researcher and the research participants with the purpose of understanding how the children knew about "electricity" and "water" in the two natural picture books before we conducted guide book of the scientific picture books. We also have them recall old experiences through things and topics in the surrounding environment.

\section{Data Collection and Analysis}

This research involves case study, exerts natural science picture books to proceed dynamic parent-child co-reading for data collection, and adopts observation and semi-structural interview to do research. What follows explains methods of data collection and analysis:

\subsection{Range of Data Collection}

(1) Recording and Point Video Taking: Since the guide reading was also conducted by the researcher, observation records could not be taken during guide reading. Therefore, we adopted retrieval records with recording and whole-process video taking to aid data logging, and converted recording data to transcription before coding and saving.

(2) Observation Record after Parent-child Co-reading: Parent-child co-reading record refers to activity record after the researcher/research participants/research subject had parent-child co-reading.

(3) Suggestions from Research Participants: The researcher invited the research participants to suggest, feedback, and assist manual operation after guide reading.

\subsection{Data Organization and Analysis}

(1) Data Organization: The collected data presents diversity, including recording, whole process video taking, record of parent-child co-reading, suggestions from the partners, self-feedback data after guide reading for the research subject, and etc. for analysis.

(2) Data Analysis: The researcher collected data and read the transcription's content repeatedly. Then, the related content was marked, classified, and generalized for comparison with relative literature, analysis, and interpretation. After addition, by discussing with the research participant (research subject's father), the researcher invited the instructor and experts to correct the data in order to enhance diversity in analysis and objectivity.

\subsection{Reliability of Data: Triangulation of Diversified Data}

The researcher converted co-reading's recording and video data to transcription in order to raise accuracy of data. Then, in coordination with diversified data like observing record, retrospective notes and interviews, the researcher conducted triangulation and comparison to enhance objectivity and reliability of the collected data. 


\subsection{Research Participants}

On completing each co-reading activity, the researcher discussed with the research participants, and organized and collected the viewpoint data in discussion in the observing record.

\subsection{Research Ethics}

The whole research process was completed in considerations of research ethics with premise of the research subject's physical and mental condition, intention, and interest.

\subsection{Research Findings}

To conclude, the KWL strategies were used for parent-child co-reading the natural science picture books in this research, and it has been verified that parent-child co-reading natural science picture books can enhance the children's scientific literacy. Children have higher interest in absorbing and applying natural science knowledge, as well as more positive attitude of exploring science. In the end of the study, the children no longer rejected natural science books, but concerned and shared scientific knowledge by the newspapers as well as doing experiment on textbooks at home by themselves. Most importantly, the children became more involved with science exploration activities. In short, the parent-child co-reading strategies for the natural science picture books in this research signifies exertion of natural science books with the three elements in KWL teaching strategy K, W, L (what do I know , what do I want to know, what did I learn)for parent-child shared reading natural science picture books have enhanced the children's scientific literacy,

\section{Different Children have Different Learning Styles}

Case-1 is a mastery-typed learner who loves to absorb concrete information and deal with information step by step. Besides, she judges learning value based on clarity and practicality, and prefers definite instruction and clear steps for her to follow. She is not interested in natural science picture books and reads books according to strategies provided by the researcher. Case- 2 is a self-expression-typed learner who employs feelings and emotions to construct new ideas. She prefers open questions, and seeks for unique and creative methods to express questions she likes. She likes natural science picture books and actively provide the reading method she feels like.

Different Children have Different Parent-child Co-reading Strategy for Natural Science Picture Books

Due to different learning styles of Case-1 and Case-2, the researcher grasped children's prior experiences before guide reading. In addition, the researcher conducted guide reading according to learning style. She also modified times of guide reading for the two subjects, and proceeded with different co-reading methods. In guide reading, she connected children's old experiences and interest to develop questions. In daily time, she also took part in scientific exploration activities and shared natural science issues through communication and discussion.

\subsection{Methods to Raise Children's Willingness of Reading Natural Science Picture Books}

In this research, in addition to parent-child co-reading natural science picture books, the researcher also aided it with manual operation of experiments, participation in scientific exploration activities, and sibling co-reading in order to raise children's willingness of reading natural science picture books, as described below:

\section{(1) Manual Operation of Experiments to Arouse Learning Motivation}

The guide reading strategy "recite word by word" is not suitable for application to natural science picture books. To learn from practical manual operation can raise children's willingness of reading natural science picture books. For almost one year from the pilot study in the beginning to the end of the formal guide reading process, the researcher employed natural science picture books with aid of practical manual operation and the living environment to conduct parent-child co-reading. The researcher considers that it is not enough for the children to read on their own; rather, we must use natural science picture books systematically to help them organize, construct, and cognize scientific concepts. From observing and analyzing the whole process of guide reading, it is found that not all scientific concepts, natural science knowledge, scientific skills, and so on can be obtained through children's own observation and individual attempts and exploration. Perhaps, some concepts can be perceived through accumulation if living experiences, but whether they can be perceived sufficiently is unknown. Only if the adults can offer scaffolding timely, children's scientific literacy can be raised.

\section{(2). Participate Scientific Exploration Activities in Daily Life to Provide Knowledge Communication Platform}

The best methods to cultivate scientific literacy is to participate in knowledge seeking process, so that children can have the chance to present their own scientific knowledge or enhance their understanding of science related issues, their learning interest, and scientific literacy. From the whole research process, it is found that the process of seeking for knowledge is an important link in cultivating scientific literacy. Nevertheless, the process of exploring science often takes longer time. If we can conduct one-to-one instruction, the learners' learning effect will be better. To compare with school, time for parent-child exploring science is often more flexible, and the extension discussion and exploration is often more profound. Explorative activities increase students' natural science 
knowledge, and children can have manual operation of scientific skills. Moreover, children can perceive nature of science, and further achieve the goal of fostering the educative learners to have basic scientific literacy.

\section{(3). Exert Sibling Co-reading to Enhance Interest in Learning}

By means of descriptive, comprehensive, and common conscious co-reading model, the research subjects held easy and natural attitudes. They recited text in picture books, discussed, and shared story content in process of co-reading. By inserting games in daily interaction, the sisters show their affection naturally. Unconsciously, they shared scientific knowledge they saw and heard. For example, the sisters decorated the guide reading situation. Since children's living experiences are meaningful to interpretation of scientific knowledge, the scientific knowledge system under the experiences is also meaningful.

\section{(4). Connect Children's Interest and Living Context}

When reader holds positive reading attitudes towards specific reading theme, he/she can thrust more attention and obtain more meanings in process of reading. In other words, when reader has positive reading attitudes, what he/she obtains will be enjoyable reading as well, learning to constructing positively cognitive reading behaviors.

\subsection{Reading Strategies for Natural Science Picture Books Helpful for Children's Scientific Literacy}

(1) Select appropriate natural science picture books for different children

Regarding selecting picture books, it has to be based on different age and learning style, and try to start at children's living context so that their reading motivation can be triggered. Besides, if the guide reading teacher like the content of natural science picture books, and can grasp basic principles in guide reading, their interest in reading natural science picture books will be raised. In this research, it is also found that when the order of co-reading is "from difficult to easy", children will have even better learning effect.

\section{(2) Exert Diversified Guide Reading Strategies for Natural Science Picture Books}

Parent-child co-reading is wonderful. Through dialogue, children's knowledge grows, and they got chances for affection communication. Therefore, in guide reading period, if the reading guider can control question proposal, skills and order of dialogues, children's dynamics of knowledge seeking will be activated. For question proposal, the reading guider can convert from structure-based choice questions to semi-structure based SAQP, and develop the questions into open essay questions. Visible knowledge is attractive for the learners, and manual operation has children enjoy learning in games, making them ignore the serious scientific theories. In process of co-reading, the researcher extended the theme in the picture books for extended reading through collecting related scientific knowledge by information media. Besides, the researcher used the collected information to discuss wand manually operate with children. Information media resources refer to various kinds of audio/video media like TV programs, films, recording media, computer software/hardware, and internet resources.

\section{(3). Turn Difficult Scientific Theories to simple and understandable Living Science Common Knowledge}

Darwin indicated that content of science is "facts and rules". The British Science Commission defined "Science": Science means seeking knowledge, understanding mother nature, and comprehending the society on basis of daily phenomena.

\subsection{Strategies to Enhance Scientific Literacy after Guide Reading}

(1) Explorative Activities in Science and Technology Museum: The methods to explore science can be obtained through learning. Explorative activities raises students' natural science knowledge, while manual operation offers chance for them to practice.

(2) Seek for Science through Parent-child Games: When family plans a trip, the researcher would purposely doing some work so as to observe scientific phenomena and create some science-related talking topics, By this way, the researcher can use trifle time to converse with the children as well as achieving learning effect of teaching in pleasure.

(3) Discover Science Application Examples in Daily Life: For scientific principles in daily life, the public are always semi-understanding. For example, they would say "electricity saving bulbs can save electricity, and filament bulbs will raise the indoor temperature" or "air conditioner wastes electricity, so it is not environmental protective".

(4) Re-read Natural Science Picture Books with the Same Theme but Different Authors: There are surprisingly plentiful amount of Natural Science Picture Books with the Same Theme in each publish company. The researcher provided children another picture book with the same theme. For example, "insulator" is also called "'dead conductor in some books.

(5) Accompany the Children to Watch Natural Science Programs: Scientific programs present natural science knowledge, spirit, attitudes, principles, trends, and application to the audience, so that science is understandable and friendly. Watching scientific programs with children will internalize their interest in science.

To sum up, the purpose of exploring parent-child reading natural science picture books is to lead the research subjects to systematically shape their scientific literacy. The researcher used KWL three-stage strategies as the framework, and had it aided by questions, discussions, sharing, feedback, and retrospection in order to be integrated into experimental activities of natural science picture books. 
On the other hand, the whole process of guide reading was proceeded with philosophy as "based on children's interest", the research subjects can autonomously and automatically explore natural phenomena, and thus obtain experiences and laws through generalized thinking. Besides, they constructed deductive ability through imagination and creative thinking, and interpret and prove the facts by means of inference thinking. The researcher's parent-child co-reading strategies for natural science picture books are diversified and dynamic, and she called such activities related to parent-child co-reading as "dynamic parent-child co-reading". From the whole research process, it can be observed that using natural science picture books to proceed dynamic parent-child co-reading is helpful for children's constructing scientific literacy.

\section{Suggestions}

\subsection{Suggestions for Parents through Dynamic Parent-child Co-reading}

(1) Pay Attention to Selecting Natural Science Picture Books: It is suggested that parents seek for subject of picture books in their own living context, and construct new knowledge upon old experiences. In addition, reading guider has to control the content of natural science picture books, because overly simple and unchallengeable learning will wear children's learning willingness out. The knowledge learning method "from difficult to easy" can enable children to accumulate natural science knowledge and cultivate their positive mental attitude towards scientific principles gradually, which is beneficial for learning.

(2) Exert Dynamic Parent-child Co-reading Strategies: Both creating repeated reading chances and paying attention to making questioning skills concentrate on children will enhance their sense of learning participation and trigger children's learning motivation. Besides, manual operation of experiments and taking part in scientific exploration activities help shape children's scientific literacy: (3) Communicate natural science related knowledge and learn positive scientific exploration attitudes. With two major directions in parent-child co-reading skills: "reciting word by word", or "adding ingredient"-- telling a story by personal narrative style, and proposing questions and discussing while describing. The former is mostly conducted by parents, and the children just listen, both of them get indulged in the book's content. The latter refers to parents offer chance for the children to publish, read, and explore through guidance and enlightenment, and listen to children's ideas and viewpoints and exchange opinions and feedbacks by means of questions.

\subsection{Suggestions for School Teachers}

(1) On Natural Science Teaching
In Grade-1-9 Curriculum Guidelines, Ministry of Education's "cultivating ten abilities for the children" is good, and its intention for curriculum design is fair as well. Teachers in the first educational site can understand the philosophy in the curriculum guidelines, and they can consult the implementation methods and teaching skills in the guidelines, which should be helpful to teaching in class. Besides, manual operation programs cannot be omitted, and reciting word by word teaching will only choke students' learning willingness in learning natural science, and deepen the myth that science is mysterious. The researcher agrees with it. Teachers are no way almighty, regardless of their being an "expert" rather than a "general talent". However, natural science in elementary stage is common knowledge instead of knowledge for teachers with professional trainings. Therefore, the researcher provided four suggests for the school teachers: A. Cultivate interest in natural science-where there is interest, there is dynamics. If teachers can enhance their own scientific literacy, teaching will be even fun. B. Conduct "manual operation" program--"learning from doing" experiences will make students' learning even more effective. C. Make good use of teaching resources-consulting teacher's guidance manual to prepare for teaching. Decorate the classroom with theme posters and wall papers provided by the book vendors. D. Cooperative teaching-- the concept that parents assist school's teaching is getting better. If the teacher can rely on parents' professional efficacy, students' outcome from natural science will be consolidated. In addition, coordinative teaching among teachers can be used to activate natural science programs.

\section{(2) On Guide Reading of Natural Science Picture Books}

As far as guide reading Natural Science Picture Books in school, the research suggests teachers use group discussion by adopting "heterogeneous grouping" in differentiated teaching, and report the results of group discussion. During discussion, teachers can refer to $\mathrm{K}$ (what do I know), W (what do I want to know), and L (what did I learn) as axis to cultivate students' ability of constructing knowledge.

\subsection{Retrospection}

\section{Personal and Children's Growth}

Since the researcher graduated from science and technology department, she set the outline as natural science. Because of being mother, she read hundreds of picture books, and trust in power of picture books. Due to the research process lasting for nearly a year, the kids and the researcher harvest abundantly, as shared below:

\section{(1) Research Concept Design Period}

In order to select a favorite Natural Science Picture Books, the researcher read books with children's science books published by more than 10 publish companies. She try to perceive the author's nationality, writing style, and the translator's translating style, as well as recommendation 
articles and the content of scientific knowledge to judge whether it is proper to serve as children's guide reading books. In this period, she transformed from declining natural science to loving natural science gradually, and she firmly believe the importance of natural science and accumulation of scientific knowledge.

As for the children, they followed me to browse the book, eager to provide some opinions to Mother. They would comment their favorite comics seriously. She was quite impressed that in order to persuade me to buy Natural Science comics published by specific publish company, Shao-yo shared knowledge of "characteristics of wave" with me, for she was afraid that the researcher would consider comics as a lack of knowledge. When being asked, "where did you find the comics", she replied the Natural Science picture books she wanted to read. During this period, children accumulated a lot of scientific knowledge and learned communication and expression. I also modified my attitudes towards comics.

\section{(2) Guide Reading Period}

The researcher was worried that she would make the children resist against reading Natural Science picture books instead of triggering their interest. Therefore, when she selected the research tool, she practice guide reading for several times-- If the children do not understand the terminology, how would the researcher explain it with language they can understand; for different kid, how does the researcher modify the content of guide reading book. In such way, the skills of telling a story has become even more proficient, and the question proposal methods and points were generated in this period. From having the kids follow my pace, and collaborating with their tempo, to reaching the parent-child co-reading agreement unconsciously and enjoying wonderful co-reading, in playing the role as Mother, the researcher become even more democratic.

Children's transformation are the most significant point. Shao-shi did not resist against Natural Science book series, and Shao-yo simply love to read Natural Science books. They would fetch a series of books for discussion. When Shao-yo did not understand certain concept, she would come to ask Shao-shi. Children and the researcher therefore established to prove personal argument based on valid scientific proofs. We do not persuade others to identify with our own attitudes any longer, and this is the sweetest fruit for us.

\section{(3) Present Stage}

On the road of education, the researcher did not trust his husband's way of teaching at first, considering that he was too straightforward, overly stick to some principles that increase children's burden. After this research process, the researcher started to believe that "where love exists in education, there is no hindrance". Kids have developed mutual agreement with their father, and established even more profound affection with him. Upon any questions on knowledge, they resort to father more often than coming to me, and the reseracher obtain more time re-ponder on the direction for my future, and how to orientate the role as a mother.

\section{REFERENCES}

[1] PISA in Taiwan, Content of Evaluation, Extracted from http://te.ntpc.edu.tw/ezfiles/6/1006/img/82/06-12.pdf on January 10. 2012.

[2] Learning Strategy Net--Reading Skills, Center for Teaching and Development, Taiwan University, obtained from http://ctld.ntu.edu.tw/ls/strategy/data.php?c1 $=5 \& \mathrm{c} 2=11$ on April 20, 2014

[3] C.W. Wang, Exploration on Impact of Parent-child Co-reading Scientific Text on Forming Scientific Concepts (unpublished Master Thesis), National Taichung University Of Education, Taichung, 2010.

[4] F. H. Tien, Introduction to Learning Styles, E-paper of Center for Teaching and Development, Taiwan University, 2014.

[5] Ho Shiang-ju, Huang Chin-shung, Connecting Language and Scientific Learning--KWL Teaching Strategy for Application to Early Childhood, Periodical of Children's Education Research, Vol: 1, 67-81, 2012.

[6] K. Yung. On Process of Implementing Journey of Parent-child Co-reading Picture Books, Early Childhood Education Information, Vol, 209, 42-48. 2008.

[7] V. L. Akerson, \& D. L. Hanuscin. Teaching the nature of science through inquiry: The results of a three-year professional development program. Learning, Teaching, and Curriculum presentations (MU), 2010.

[8] S. Shaywitz. Overcoming dyslexia: A new and complete science-based program for reading problems at any level. Vintage, 2008.

[9] 2010 National Year of Reading Popular Science, "One Popular Science Book For Everyone to Read Popular Science Reading", March 10, 2014 from http://popsci.lib.ntnu.edu.tw /about/about.jsp

[10] K. Ansberry, \& E. R. Morgan. Picture-perfect science lessons: Using children's books to guide inquiry. NSTA Press. 2010

[11] S. S. Bracken, \& J. E. Fischel. Family reading behavior and early literacy skills in preschool children from low-income backgrounds. Early Education and Development, 19(1), 45-67, 2008.

[12] Y. C. Cheng. Research on Sibling Interaction during Co-reading (unpublished master thesis), National Chia Yi University, Chia-yi, 2011.

[13] C. C. Hsu. Influence of Reading Popular Science Picture Books' on Grade-4 Students' Attitudes towards Science, National Tainan University, Tainan, 2008.

[14] F. C. Hus. Kindle the Explorative Soul of Little Child, Common Wealth Magazine No. 536, Taipei: Common Wealth, 2013.

[15] P. Mantzicopoulos, \& H. Patrick. Reading picture books and 
learning science: Engaging young children with informational text. Theory Into Practice, Vol: 50, No.4, pp. 269-276, 2011.

[16] C. J. Wu. Research on Science Picture Books for Scientific Concept Learning of Students with Different Cognitive Styles (unpublished master thesis), Kaohsiung Normal University, Taiwan, 2006.

[17] C. Chiong, J. Ree, L. Takeuchi, \& I. Erickson. Print books vs. e-books: Comparing parent-child co-reading on print, basic, and enhanced e-book platforms. The Joan Ganz Cooney Center, 2012.

[18] A. R. Lauricella, R. Barr, \& S. L. Calvert. (2014). Parentchild interactions during traditional and computer storybook reading for children's comprehension: Implications for electronic storybook design. International Journal of Child-Computer Interaction, 2(1), 17-25.

[19] D. M. Ogle. KWL: A teaching model that develops active reading of expository text. The reading teacher, 564-570, 1986.

[20] A. L. Herrell, \& M. L. Jordan. 50 strategies for teaching English language learners. Pearson, 2015.

[21] R. Bybee, B. McCrae, \& R. Laurie. PISA 2006: An assessment of scientific literacy. Journal of Research in Science Teaching, Vol. 46, No. 8, 865-883, 2009.

[22] R. Bybee. Scientific literacy. Encyclopedia of Science Education, 944-947, 2015.

[23] P. A. Ganea, M. B. Pickard, \& J. S. DeLoache. Transfer between picture books and the real world by very young children. Journal of Cognition and Development, Vol. 9, No. 1, 46-66, 2008.

[24] Y. Y. Yang. Scientific Story Program's Influence on Grade-5 Students' Attitudes towards Nature of Science and Science (unpublished master thesis), National Hua-lien Normal College, Hua-lien, 2008.

[25] L. D. Yang. Mobile Study on A Early Childhood Education Teacher's Practicing Natural Science Exploration, (unpublished master thesis), National Ping-tung Normal University, Ping-tung, 2010.

[26] C. C. Yang, G. J. Hwang, C. M. Hung, \& S. S.Tseng. An evaluation of the learning effectiveness of concept map-based science book reading via mobile devices. Journal of Educational Technology \& Society, Vol: 16, No. 3, pp167-178, 2013.

[27] B. B. Armbruster. Put reading first: The research building blocks for teaching children to read: Kindergarten through grade 3. DIANE Publishing, 2010.

[28] M. Fleer. Science for children. Cambridge University Press, 2015.

[29] J. Holbrook, \& M. Rannikmae. The nature of science education for enhancing scientific literacy. International Journal of Science Education, Vol. 29, No. 11, 1347-1362, 2007.

[30] C. S. Lai. Science Education and Science Games in Elementary School, National Taipei University of Education, Taipei, 2012.
[31] M. van den Heuvel-Panhuizen, S. van den Boogaard, \& B. Doig. Picture books stimulate the learning of mathematics. Australian journal of early childhood, Vol. 34, No. 3, pp 30-39, 2009.

[32] P. A. Ganea, L. Ma, \& J. S. DeLoache. Young children's learning and transfer of biological information from picture books to real animals. Child Development, Vol. 82, No. 5, 1421-1433, 2011.

[33] M. Saçkes, K. C. Trundle, \& L. M. Flevares. Using Children's books to teach inquiry skills. YC Young Children, Vol, 64, No. 6, 24, 2009.

[34] I. Elia, van den Heuvel - M. Panhuizen, \& A. Georgiou. The role of pictures in picture books on children's cognitive engagement with mathematics. European Early Childhood Education Research Journal, Vol. 18, No. 3, 275-297, 2010.

[35] H. H. Lin, C. C. Liu, S. W. Lin, H. Li, Outcome Report of Taiwan's Attending PISA 2006, Research Project of National Science Committee, Executive Yuan (No. NSC 95-2522-S-026-002), Unpublished, Huan-lien County, 2008.

[36] Y. G. Lin, E. T. Chin, H. L. Tuan. Exploring of a Junior High School Teacher's Developing Math Exploration Teaching with Narrative Exploration, Educational Science Research Periodical, Vol: 55, No.3, 1-32, 2010.

[37] H. A. Schweingruber, R. A. Duschl, \& A. W. Shouse. (Eds.). Taking Science to School: Learning and Teaching Science in Grades K-8. National Academies Press, 2007.

[38] J. A. Williams, C. Podeschi,, N. Palmer, P. Schwadel, \& D. Meyler. The Human - Environment Dialog in Award winning Children's Picture Books*. Sociological Inquiry, Vol, 82, No.1, pp145-159, 2012.

[39] R. Carson. The sense of wonder. Open Road Media, 2011.

[40] L. B. Smolkin, E. M. McTigue, C. A. Donovan, \& J. M. Coleman. Explanation in science trade books recommended for use with elementary students. Science Education, Vol. 93, No. 4, 587-610, 2009.

[41] X. Yu. Exploring visual perception and children's interpretations of picture books. Library \& Information Science Research, Vol. 34, No. 4, 292-299, 2012.

[42] C. Sagan. Demon-haunted world: science as a candle in the dark. Ballantine Books, 2011.

[43] S. M. Landt. Using picture books to arouse interest in the study of geographic areas. The Social Studies, Vol. 98, No. 1, 9-12, 2007

[44] K. R. Ansberry., \& E. R. Morgan. More Picture-perfect Science Lessons: Using Children's Books to Guide Inquiry, K-4. NSTA Press, 2007.

[45] S. E. Mol, A. G. Bus, M. T. de Jong, \& D. J. Smeets. Added value of dialogic parent-child book readings: A meta-analysis. Early Education and Development, Vol. 19, No.1, 7-26, 2008.

[46] P. A. Ganea, C. F. Canfield, K. Simons-Ghafari, \& T. Chou. Do cavies talk? The effect of anthropomorphic picture books on children's knowledge about animals. Frontiers in psychology, 5, 2014.

[47] L. Vygotsky. Interaction between learning and development. Readings on the development of children, Vol. 23, No. 3, 
$34-41,1978$.

[48] D. P. Ausubel. The acquisition and retention of knowledge: A cognitive view. Springer Science \& Business Media, 2012.

[49] D. A. Kolb, R. E. Boyatzis, \& C. Mainemelis. Experiential learning theory: Previous research and new directions. Perspectives on thinking, learning, and cognitive styles, Vol. 1, 227-247, 2001.

[50] N. K. Duke, \& P. D. Pearson. Effective practices for developing reading comprehension. Journal of education, 107-122, 2008.

[51] K. Hershberger, C. Zembal-Saul, \& M. L. Starr. Evidence helps the KWL get a KLEW. Science and Children, Vol. 43, No. 5, 50-53, 2006.

[52] A. Kitsantas, H. W. Ware, \& R. Martinez-Arias. Students' perceptions of school safety: Effects by community, school environment, and substance use variables. The Journal of Early Adolescence, Vol. 24, No.4, 412-430, 2004.

[53] S. S. FU. Research on the Influence of KWL Media Teaching Strategy on the Learning Achievement of the Unit of "An Earthquake" of 5th Grade Students of Elementary School, Unpublished Thesis, National Taipei University, Taiwan, 2006.

[54] R. G. Miller. Thinking like a scientist: Exploring transference of science inquiry skills to literacy applications with kindergarten students. Electronic Journal of Literacy through Science, Vol. 6, No. 1, 41-52, 2009.

[55] C. Zembal Saul. Learning to teach elementary school science as argument. Science Education, Vol. 93, No. 4, 687-719, 2009. 